\title{
MANTLE XENOLITHS OF THE GRIB PIPE, ZIMNY BEREG AREA, RUSSIA
}

\author{
Ludmila Sablukova $^{1}$, Sergei Sablukov', Elisey Verichev ${ }^{2}$ and Nikolay Golovin ${ }^{3}$ \\ ${ }^{1}$ TsNIGRI, Moscow, Russia; ${ }^{2}$ ZAO "Arkhangelskgeolrazvedka", Russia; ${ }^{3}$ OAO “Arkhangelskgeoldobicha", Russia
}

In all known diamondiferous pipes of the Zimni Bereg area, diamonds are sharply dominated by rounded "Uralian-type" crystals (Zakharchenko et al., 1990), with the only exception in the Grib pipe where most of the diamonds are flat-faced octahedral crystals (Verichev et al., 1999; Sergeeva, 2000). This is why the examination of deep-seated nodules from the Grib pipe kimberlite rocks is of great interest. Our collection of mantle nodules was collected from core samples, with a total of about $6,000 \mathrm{~m}$ core analyzed during 1996-2002, and it consists of more than 500 nodule samples, not counting numerous xenocrysts.

Mantle xenoliths are much more abundant in the Grib pipe than in other Zimni Bereg pipes, occurring as frequently as up to 3-5 xenoliths per meter of core. Deep-seated inclusions from the Grib pipe are, in general, rather large (up to $22 \mathrm{~cm}$ ), with relatively weak secondary alteration, which makes this pipe unique among the Zimni Bereg pipes. The deepseated inclusions occurring in the Grib pipe kimberlites are widely diversified (Figure 1), from various ultramafic (including metasomatites and complex rocks with complicated structure and composition) to mafics with abundant xenocrysts and megacrysts.

\section{ULTRAMAFICS}

\section{The Mg-Al series ultramafics}

The ilmenite-free ultramafics of the $\mathrm{Mg}-\mathrm{Al}$ magmatic series (after Marakushev, 1984) are sharply dominated by rocks of the $\mathrm{C}_{2}$ grospydite depth subfacies (22-34 kbar, after Sobolev et al., 1972), most of them being essentially pyrope rocks, such as lherzolite, dunite, clinopyroxenite and websterite. The texture of these rocks varies from fine-grained to coarse-grained, with allotriomorphic, hipidiomorphic and panidiomorphic (or protogranular) textural varieties. Typical cataclastic rocks are rare. The $C_{3}$ cohesite depth subfacies (34-40 kbar) inclusions are also sharply dominated by pyrope rock varieties (dunite and lherzolite), with just a few inclusions of chrome spinel ultramafics. Spinel peridotites of lowpressure depth facies, while more abundant than chrome spinel peridotites, also occur as only single inclusions of spinel dunite and harzburgite of the B spinel-pyroxene facies (7-17 kbar) and garnetized spinel lherzolites of the $C_{1}$ spinel-pyrope subfacies (17-22 kbar). In general, the $\mathrm{Mg}-\mathrm{Al}$ series nodules commonly contain phlogopite, with not one of the analyzed xenoliths showing any evidence of metasomatic amphibolitization so typical of xenoliths from similar $\mathrm{Mg}-\mathrm{Al}$ series ultramafics from pipes of the Zolotitsa and Pachuga fields (Sablukov et al., 2000).

The TP formation parameters were calculated for the $\mathrm{Mg}$ Al series nodules from mineral chemistry of the pyrope + clinopyroxene paragenesis, which is commonly most abundant in different nodule varieties. Temperature values were determined from the EG79T geothermo meter (Ellis and Green, 1979), and pressure values were calculated using the NS94P method (Nikitina and Simakov, 1994). The calculations yielded a temperature range of $749-1294^{\circ} \mathrm{C}$ and a pressure range of 26.7-49.9 kbar, which corresponds to a conductive geotherm with $40-45 \mathrm{~mW} / \mathrm{m}^{2}$.

\section{The Fe-Ti series ultramafics}

Xenoliths of the Fe-Ti series ultramafics (after Marakushev, 1984), while less abundant than the Mg-Al series ones, are quite diversified. They are dominated by ilmenite-rich varieties of olivinite, lherzolite, harzburgite, orthopyroxenite and clinopyroxenite. Pyrope-ilmenite olivinites and lherzolites, which are less abundant, commonly contain irregular segregations of high-Ti, lowCr orange pyrope G1 group (after Dawson and Stephens, 1975). The text ure of these rocks is as diversified as that of the $\mathrm{Mg}-\mathrm{Al}$ series ultramafics, however with somewhat greater abundance of cataclastic rocks and rocks with hypidiomorphic to sideronitic texture due to the presence of irregular ilmenite segregations. In addition there is a separate group consisting of a few peculiar pyrope-rutile peridotite xenoliths with panidiomorphic-granular structure, where Cr-rutile takes the place of ilmenite, and orange pyrope is similar in composition to pyrope in pyrope-ilmenite peridotites. Lastly, there are "mixedtype" xenoliths of ilmenite-rutile ore olivinites consisting of medium-crystalline, panidiomorphic-granular ilmenite + rutile aggregate with relatively large segregations of altered olivine.

\section{Metasomatites}

A peculiar and quite abundant group of ultramafic inclusions includes xenoliths of metasomatic, predominantly clinopyroxene-phlogopite rocks. Rocks of this group are sharply dominated by glimmerites 


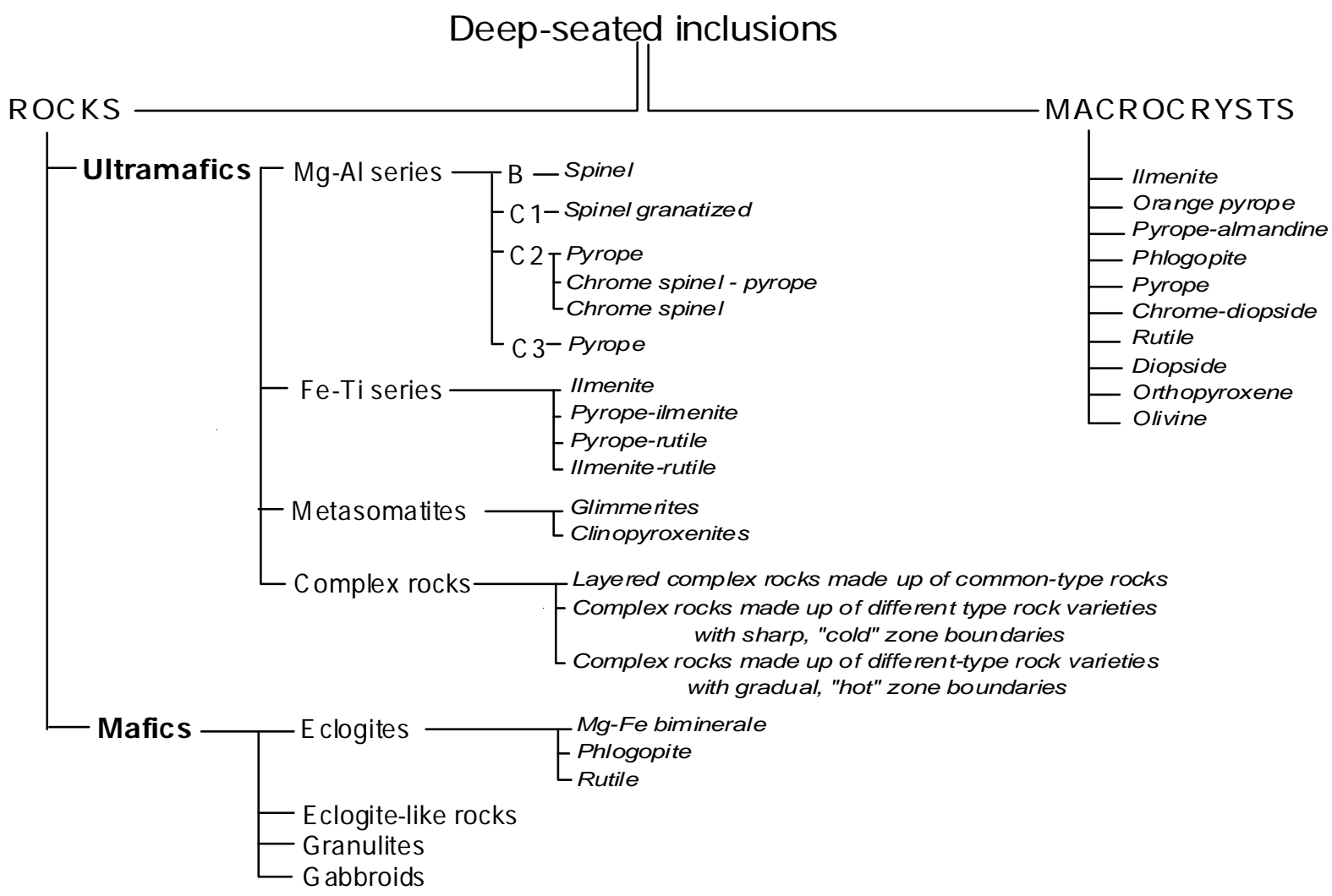

Figure 1. Classification of the deep-seated inclusions from the Grib pipe kimberlites

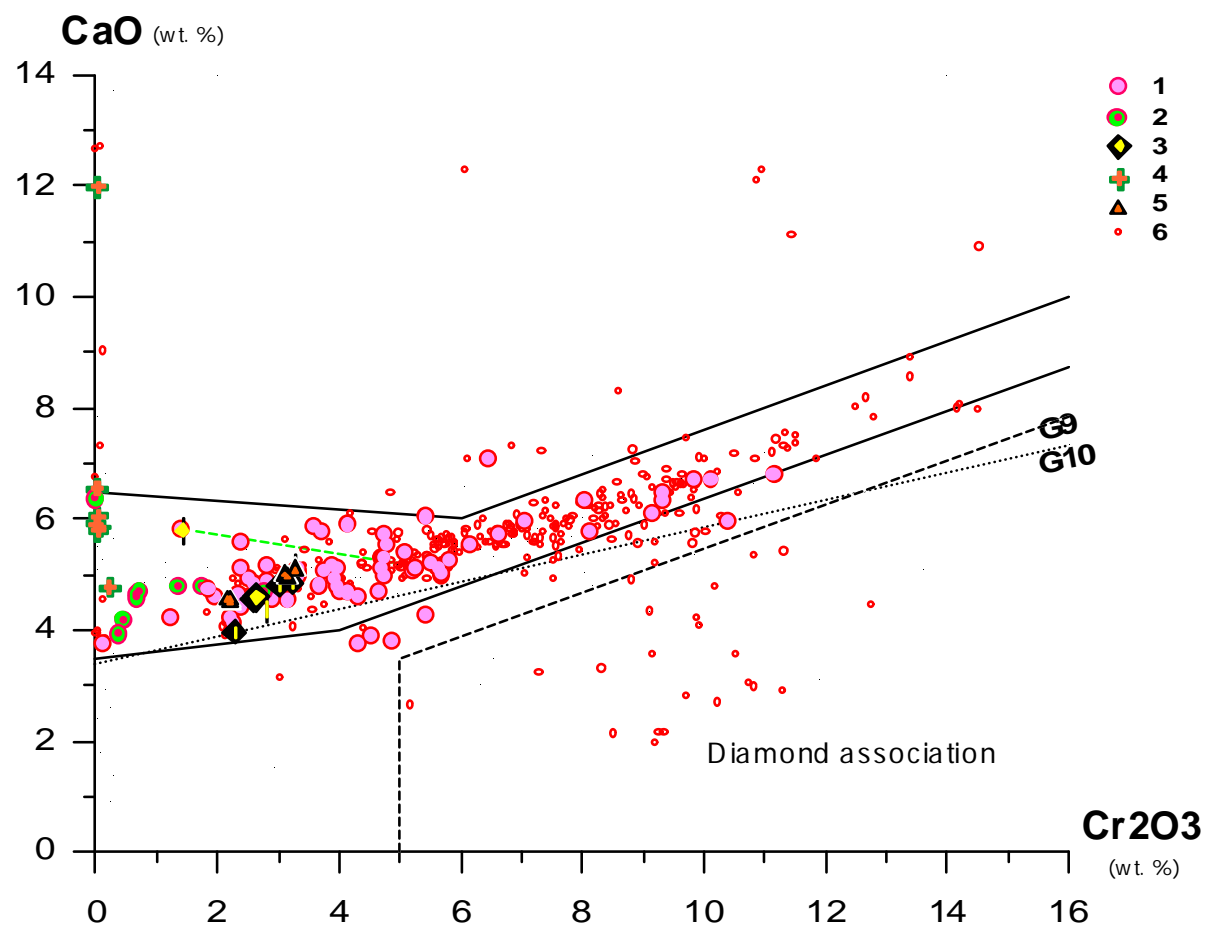

Figure 2. Composition of garnets from the Grib pipe mantle nodules (diagram after Sobolev, 1974) 1 - pyrope peridotites, 2 - pyrope clinopyroxenites, 3 -pyrope-ilmenite and pyrope-rutile peridotites, 4 - eclogite and eclogite-like rocks, 5 - megacrysts, 6 - pyrope from kimberlite concentrate.

The green line connects the point of compositions different grains from one complex rock sample. 
(phlogopite, clinopyroxene-phlogopite and olivinephlogopite varieties) and phlogopite clinopyroxenites, more rarely containing minor amounts of ilmenite, rutile or pyrope. The texture of these rocks is fine- to coarse-grained, predominantly allotriomorphic, hypidiomorphic, panidiomorphic, poikilitic and, rarely, graphic. The structure of the metasomatites is commonly heterogeneous, occasionally taxitic.

\section{Complex rocks}

The size of the nodules is large enough to enable one to identify the complicated structure of some of the xenoliths obviously made up of complex rocks. These inclusions have a zoned, banded structure (Harte et al., 1973) consisting of several (most commonly, two) different petrographic rock varieties. The following three types of complex rock were identified based on the set and composition of minerals in different structural zones of the xenolith and on the characteristics of the boundary (interface) between two adjacent zones within a nodule:

\section{A) Layered complex rocks made up of common-type rocks}

In these complex rocks different zones within a xenolith consist of rocks being, in general, all of the same petrographic type, with only quantitative petrographic distinctions and unclear boundaries between the zones. Two distinct varieties of this complex rock type were identified: (1) massive pyrope dunite + zone with parallel alternating layers of pyrope clinopyroxenite and pyrope-olivine websterite, or pyrope dunite + zone of pyrope websterite, and (2) pyrope orthopyroxenite + olivinepyrope clinopyroxenite. In general, like minerals in different zones of these xenoliths are of like appearance and composition. Complex rocks of this type are similar to fragments of rocks of cumulus origin from layered plutons (intrusions), or to fragments of metamorphosed rocks of this type.

\section{B) Complex rocks made up of different- type rock varieties with sharp, "cold" zone boundaries}

Different zones within the xenoliths consist of qualitatively different rocks, dissimilar in petrography and mineral chemistry, one of the zones (and, in some cases, both of them) consisting of a metasomatic rock. The boundaries between the zones are sharp, well defined, or "cold", which means no structural or compositional changes in the zones away from the boundary. The following two varieties of this complex rock type were identified: (1) massive pyrope lherzolite + layered phlogopite pyroxenite consisting of predominantly phlogopite and predominantly clinopyroxene layers interbedded subparallel to the zone boundary; massive olivinite + rutile-olivine-phlogopite glimmerite, and (2) massive finecrystalline pyrope-olivine-phlogopite glimmerite + phlogopite-bearing clinopyroxenite with drusy structure. Complex rocks of this type are similar to fragments of veinlets and/or segregations of various metasomatic rocks, including those with preserved primary rock fragments.

\section{C) Complex rocks made up of different-type rock varieties with gradual, "hot" zone boundaries}

Different zones within the xenolith are made up of qualitatively different rocks, dissimilar in petrography and mineral chemistry, with prominent gradual change in set and composition of minerals away from the interface. This complex rock type is represented here by a single variety: protogranular pyrope wehrlite of the $\mathrm{Mg}$-Al series + ilmenite-pyrope clinopyroxenite of the Fe-Ti series. The $4 \mathrm{~cm}$ wide zone extending along the zone boundary is made up of olivine-clinopyroxene-pyrope rock (with some elements of subparallel banding) where purplish-red medium-Cr pyrope (G9 pyrope, after Dawson and Stephens) grades into orange, low-Cr, high-Ti orange pyrope (G1 pyrope), and emerald-green clinopyroxene becomes enriched with $\mathrm{Fe}$, $\mathrm{Ti}$ and $\mathrm{Al}$ and impoverished in $\mathrm{Cr}$, therewith changing its color to grass-green. Complex rocks of this type are similar to fragments of rocks that underwent "hot" contact metasomatism, looking like "skarnoids" of a sort. In the case in point, there is clear evidence of active influence of an ilmenite-pyrope ultramafic intrusion on a pyrope ultramafic massif. Most inclusions of this type show only discontinuous elements of such rock alteration, including evidence of gradual purplish-red pyrope replacement by orange pyrope or copresence of purplish-red and orange pyrope in different zones within a common xenoliths.

\section{MAFICS}

Mafic mantle nodules are mostly typical bimineral $\mathrm{Mg}-\mathrm{Fe}$ eclogites with medium to coarse-crystalline texture consisting of orange pyrope-almandine and light green omphacite. These rocks quite commonly contain varying amounts of phlogopite. Rutile-containing eclogite varieties occur more rarely.

Mafic xenoliths are dominated by eclogite-type rocks and granulites consisting of orange garnet, pall green clinopyroxene and plagioclase, with varying amounts of biotite, amphibole and opaque minerals (rutile and ilmenite). Xenoliths of these rocks are characterized by a commonly well defined banded structure and widely varying mineral modes, from nearly bimineral garnetpyroxene rocks (with a minor admixture of plagioclase) to 
garnet- and pyroxene-bearing, essentially plagioclase rocks. In addition, among mafic xenoliths are gabbroic rocks and clinopyroxenites of the "black series" consisting of a fine-crystalline, tobacco-green clinopyroxene aggregate with olivine, amphibole, magnetite and, occasionally, plagioclase admixture. Many of these xenoliths appear to be fragments of rocks of the crystalline basement and lower crust horizons rather than mantle-derived formations.

\section{XENOCRYSTS AND MEGACRYSTS}

Xenocrysts and megacrysts are abundant in rocks of the Grib pipe. Among them are large oval, subangular grains of violet and purplish-red pyrope (up to $2 \mathrm{~cm}$ ), pyrope-almandine (up to $2 \mathrm{~cm}$ ), chrome-diopside (up to $3 \mathrm{~cm}$ ), picroilmenite (up to 4 $\mathrm{cm}$ ), orange Ti-pyrope (up to $5 \mathrm{~cm}$ ), phlogopite (up to $5 \mathrm{~cm}$ ), rutile (up to $2 \mathrm{~cm}$ ), pale green diopside (up to $3 \mathrm{~cm}$ ), pale yellow orthopyroxene (up to $5 \mathrm{~cm}$ ), and yellowish olivine (up to $3 \mathrm{~cm}$ ). In addition, picroilmenite inclusions in orange garnet and orange garnet inclusions in picroilmenite also occur.

It is difficult to draw a sharp dividing line between xenocrysts and megacrysts in the Grib pipe rocks. The essential minerals of deep-seated inclusions, namely, olivine, pyrope, chrome-diopside, picroilmenite, diopside, phlogopite and rutile, are respectively identical, both in mineral chemistry and in appearance, to the same minerals occurring as isolated grains in kimberlite matrix. It is likely that thes e minerals are all products of disintegration and melting of deep-seated rocks, with different modes of occurrence reflecting different intensity of these processes.

\section{CONCLUSIONS}

The distribution of different deep-seated xenolith varieties in the Grib pipe kimberlites is shown in Figure 3A. Most of these xenoliths are nodules of various pyrope peridotites and pyroxenites related to different depth facies, whereas chrome spinel ultramafics are few. Eclogites and eclogite-like rocks are abundant. Among Fe-Ti series ultramafics, peculiar ilmenite-rutile and pyrope-rutile rock varieties occur along with common ilmenite and pyrope-ilmenite rocks. Another peculiar feature of the Grib pipe is the presence of rutile megacrysts along with "traditional" ilmenite, garnet, phlogopite, pyroxene and olivine megacrysts. The abundance of various clinopyroxene, phlogopite-clinopyroxene and phlogopite rocks may be evidence of intense mantle water-calc-alkali (K-Ca) metasomatism in rocks of the deep-seated parent mass of the Grib pipe kimberlites.
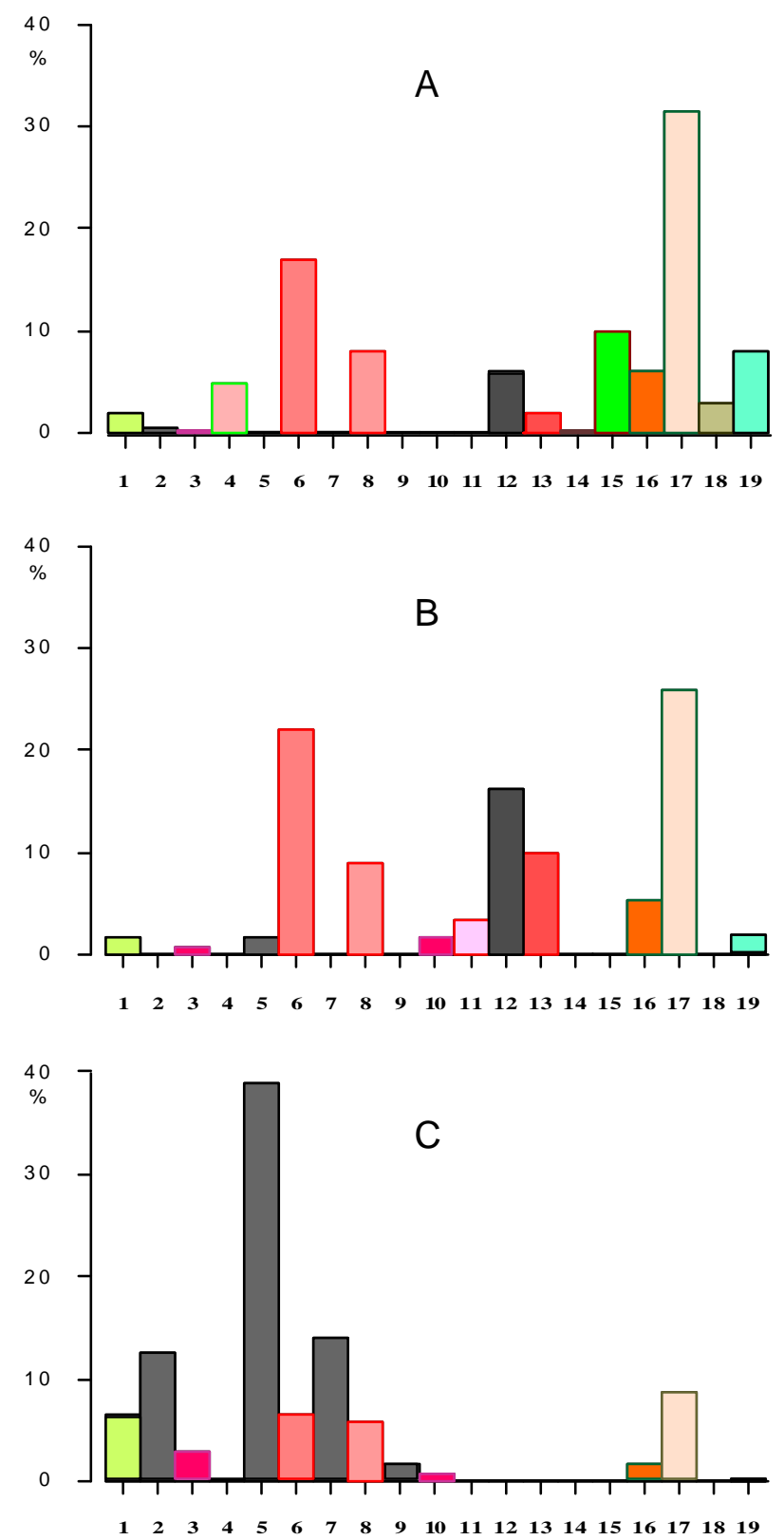

Figure 3. Distribution of various mantle nodules in the kimberlites of the Zimnii Bereg area: A - Grib pipe; B Anomaly-688 pipe; $\mathrm{C}$ - name $\mathrm{M}$. Lomonosov deposit pipes. 1 - olivinites, 2-10 - ultrabasites of the Mg-Al-series (Marakushev, 1984): 2 - spinel-pyroxene "B" facies, 3 - spinelpyropic "C1" subfacies, 4 - pyrope clinopyroxenites, 5,6 grospydite "C2" subfacies, 7,8 - coesite "C3" subfacies, 9,10 diamond-pyrope "D" facies, 11 - garnetized orthopyroxenites (3, $4,6,8,10,11$ - pyropebearing varietes); $12-14$ - ultrabasites of the Fe-Ti-series (Marakushev, 1984): 12 - ilmenitic rocks, 13 pyrope-ilmenitic rocks; 14 - rutile rocks, 15 - clinopyroxenephlogopite metasomatites, 16 - eclogites, 17 - eclogite-like rocks and granulites; 18 - gabbroides; 19 - megacrysts. 
The presence of diversified complex rock nodules suggests a complex, multi-stage history of mantle mass formation; in particular, it points to cumulustype magma segregation, development of vein-type metasomatic formation, and intrusive rock relationships resulting in the formation of "skarnoids", i.e., zones of "hot" contact metasomatism.

The set of mantle rock varieties identified in the Grib pipe is drastically distinct from that typical of the Lomonosov deposit kimberlite pipes (Al-series Zimni Bereg kimberlites (Sablukov, 1990)), being most similar to that of An-688 pipe from the Pachuga field (Fe-Ti series Zimni Bereg kimberlites). The Grib pipe differs from pipe An-688 by its higher concentration of mantle nodules, abundance of clinopyroxenites and clinopyroxene-phlogopite metasomatic rocks, and clinopyroxene, orthopyroxene, deformed phlogopite and rutile megacrysts.

In general, kimberlites of the Grib pipe are similar in the set of mantle xenoliths, in their large size and high concentration, in sharp predominance of pyrope rock varieties among the xenoliths and in geochemical and $\mathrm{Nd}-\mathrm{Sr}$ isotope characteristics of the nodules to Group 1 South African kimberlites and diamondiferous kimberlites from Southern fields of the Yakutian diamond province (except for the Nakyn field). The predominance of flat-faced octahedra among the Grib pipe diamonds also makes the Grib pipe rocks similar to Yakutian kimberlites.

This study was supported by the Russian Foundation for Basic Research, grant 01-05-64257.

\section{REFERENCES}

Dawson, J.B. and Stephens, W.E. 1975. Statistical analysis of garnets from kimberlites and associated xenoliths; J.Geol. 83, 589-607.

Ellis, D.J. and Green, D.H. 1979. An experimental study of the effect of $\mathrm{Ca}$ upon garnet-clinopyroxene $\mathrm{Fe}-\mathrm{Mg}$ exchange equilibria. Contrib. Miner. And Petrol. 71, 13-22.

Harte, B., Cox, K.G., Gurney, J.J., 1975. Petrography and geological history of upper mantlr xenoliths from he Matsoku kimberlite pipe. In: Physics and chemistry of the Eart, vol. 9 (First Int. Kimb. Conf. Cape Town, 1973). Pergamon Press, New York, pp. 477-506.

Marakushev A.A. 1984. Peridotite nodules in kimberlites and basalts as indicators of deep litosphere structure; Proc. $27^{\text {th }}$ IGC, Petrol., Sect. S.09, vol.9, Moscow, Nauka, p.153-161 (in Russian).

Nikitina, L.P. and Simakov, S.K. 1994. TERRA nova; Fifth International EMPG Symposium, vol.6, p.34.

Sablukov S.M. Petrochemical series of the kimberlite rocks Dokl. Akad. Nauk SSSR 313(4), 935-939 (in Russian).

Sablukov, S.M., Sablukova, L.I. and Shavirina, M.V. 2000. Mantle xenoliths in the Zimny Bereg kimberlite deposits of rounded diamonds, Arkhangelsk diamondiferous province. Petrologiya, 8(5), 466-494 (in Russian).

Sergeeva, O.S. 2000. Morphological peculiarity of diamonds from Grib pipe. In: Material on geology and mineral deposits of Arkhangelsk district, Arkhangelsk, 2000, pp.97-102 (in Russian).

Sobolev N.V. The deep seated inclusions in kimberlites and the problem of the upper mantle composition. 1974. Publishing House "Nauka", Siberian Branch, Novosibirsk, 264 p. (in Russian)

Sobolev, V.S, Dobretsov, N.L. and Sobolev, N.V. 1972. Classification of the deep-seated xenoliths and types of the upper mantle. Geol. and Geoph.12, 37-42 (in Russian).

Verichev, E.M., Sablukov S.M., Sablukova L.I et al. 1999. A new type of diamondiferous kimberlites of the Zimny Bereg, Arkhangelsk diamondiferous province. Dokl. Ross. Akad. Nauk. 368(2), 226-229 (in Russian).

Zakharchenko, O.D, Blinova, G.K., Botova, M.M. et al. 1990. Diamonds from kimberlite pipes of the Arkhangelsk Diamondiferous District. Final. Proc. VI All-Union meeting "The basic directions of increase of efficiency and quality of prospecting works on diamonds", Irkutsk, SSSR, pp.282-284 (in Russian).

Contact: L.I. Sablukova, TsNIGRI, Varshavskoe shosse, 129 b, Moscow, Russia, 117545, E-mail: S.Sablukov@g23.relcom.ru 